\title{
Crops in the Americas and Planting Regulations in the Southern Shaanxi Mountains*
}

\author{
Xingying Wang \\ Institute of Silk Road Studies \\ Northwest University \\ Xi'an, China 710069
}

\author{
Teng Ma \\ College of Urban and Environmental Sciences \\ Northwest University \\ Xi'an, China 710069
}

\author{
Jian Zhang* \\ Institute of Silk Road Studies \\ Northwest University \\ Xi'an, China 710069 \\ *Corresponding Author
}

\begin{abstract}
Based on the Chinese local chronicles, this article adopts a literature analysis method. From the perspective of environmental history, it discusses corn, sweet potatoes and potatoes at different times and was introduced for the purpose of economic development and the solution of famine, because of population increase, social governance and economy changes, in the way of development led to the destruction of the natural environment in southern Shaanxi. The study found that local elite groups have taken a series of measures to protect the environment: (1) Combining with the people's religious beliefs and prohibiting cultivation; (2) The government persuaded the use of widely-planted trees; (3) The official government erected a steel to ban mountainous areas; (4) The local gentleman and the merchant planted the trees spontaneously.
\end{abstract}

Keywords-tourist environment history; southern Shaanxi; Qing dynasty; American high-yield crops

\section{INTRODUCTION}

For the research on the influence and control of the introduction of crops into the eco-environment in the Americas, although there is no monograph published in the academic circles at present, there are many research papers. Zhang Xiangwen "Water and Soil Loss Caused by Maize Planting in the Mountains in the Middle and Late Qing Dynasty and Measures for Containment" [1]. Wang Xianghong, "Agricultural Development and Ecological Changes in the Qinling Mountains and Daba Mountains in the Qing Dynasty"[2]. Zhao Yongxiang "Nanshan Virgin Forest:the Forest Region's Governance and Ecological Environment of the South Qinlin Mountain in the Qing Dynasty."[3]From the perspective of historical geography, it was believed that soil erosion in southern Shaanxi was due to the cultivation of American crops in high mountain areas. However, from the perspective of environmental history, crop planting in the

*Sponsor: China Postdoctoral Science Foundation funded project (No.2015M572587); China Postdoctoral Science Special Foundation funded project (No.2017T100764); Social Science Foundation of Shaanxi Province, China (No.2015D055).
Americas interacted with changes in the environment and human reclamation activities. Therefore, the focus of this paper was to explore the process of planting in the Americas, between social and environmental changes in southern Shaanxi and human reclamation activities. And the governance measures adopted by local elite groups in southern Shaanxi promote regional economic development and environmental protection.

\section{THE INTERACTION BETWEEN THE LATER INTRODUCED CROPS IN THE AMERICANS AND THE ENVIRONMENT IN SOUTHERN SHAANXI}

After Qianlong Emperor, in order to solve the food crisis, economic development and other reasons, high-yield crops in the Americas were introduced into southern Shaanxi with great adaptability and abundant production, becoming the best choice for immigrants and indigenous peoples. The highyielding crops in the Americas and the natural environment of southern Shaanxi had experienced a complicated interaction.

However, from the results, the corn was more popular. According to Yan Ruyi, "Several years ago, the harvest in Shaanxi was taken as a large millet in the valley, and the millet was less than the corn. The corn around the mountain was all mountains in recent days... Therefore, the summer harvest saw Wheat and autumn as the corn, and with the total amount of harvest, it was determined that it was a good harvest or lack of."[4] During the Qianlong to Daoguang period, the surplus population in the southeastern provinces became the main force for the development of mountainous areas in southern Shaanxi. Corn was the guarantee for the economic development of the forests in the mountainous areas of southern Shaanxi, and indirectly it was also necessary to maintain social order. With simple, easy-to-grow, high-yield corn to maintain the survival of the needs of the migrating population, and at a low price, it had become a staple food for workers in the factories of mountains, ensuring the normal operation of the factory in the mountains. However, the nature of the natural environment in 
southern Shaanxi was: the forest is lush, the forest was dark, and the forest's public order was also difficult to maintain. [4] The factories in the mountains are all funded by immigrants. If the corn harvest is not good and the price is high, immigrants are likely to enter the mountains and become bandits, and prevention is very difficult. [5] Corn had become a major help to maintain stability in the mountains. Sweet potato was only used as an urgent emergency food for the time of famine, and it was not introduced by a wide range of residents in the mountains. Potato was the main food in the high mountains in the late Qing Dynasty. In the case of buckwheat and corn, the farmers only had a meal of potato. It could be seen that although there was no wide range of corn cultivation, it was the most important grain crop in the high mountains.

With the increase of population, the cultivation of crops in southern Shaanxi had taken an extensional path. The cultivation of high-yield crops in the Americas in southern Shaanxi had become a guarantee to solve the problem of famine at any time, but it was relying on the continuous expansion of the planting area. The interaction between man and the natural environment in southern Shaanxi gradually changed with the expansion of the planting area. After Daoguang period, the cultivation of American crops under the small-scale peasant economy reached a peak, and the population continued to grow. War and peasant uprisings aggravated regional governance pressures. What was more serious was that Western countries had completed the first industrial revolution at this time, and population pressures in the late imperial times were increasing, and long-term development had led to environmental destruction and resource decline. Traditional agricultural development had touched on "pre-modern technologies Limited," economic growth had in fact been "unsustainable," [6] which had become an opportunity for inflows of foreign capital and commodities. The status of Chinese and foreign trade had changed. The mountainous trade under the small-scale farming economy in the mountainous areas of southern Shaanxi had gradually gone bankrupt. Farmers could only survive by expanding farmland. Therefore, the combined effect of many factors was "to the Nan Shan area, the old forest was empty, whenever the heavy rain, the landscape suddenly raised, sandwiching sand and stones, along the river acres, repeatedly stamping."[7]The loss of fields, the destruction of canals, and the heavy economic burden had even led to the claim that "even more than soldiers".[1]The contradiction between the cultivation of highyield crops in the Americas and natural environmental bearing capacity in southern Shaanxi urgently required new outlets.

\section{COUNTERMEASURES FOR LOCAL GOVERNMENT AND SOCIAL ELITES}

In the late Qing Dynasty, as water and soil erosion in southern Shaanxi worsened and environmental pressures increased, local governments, social elites, and local people showed different attitudes toward increasingly serious environmental problems. The environmental ideological consciousness of the orthodox and elites represented by local government and local elites and the environmental behaviors of the ascendant and small people seeking to fulfill their hunger and hunger were suspended from each other. [8] Therefore, local governments and social elites divided public resources in the region through various methods in order to achieve the goal of reducing environmental hazards.

The system for regulating the development of mountainous areas in southern Shaanxi is closely related to the activities of the land reclamation and local religious beliefs of the immigrants in southern Shaanxi. In the traditional thinking of the Chinese people, advocating the existence of all things, various local temples worshiped by the villagers and asked for the protection of the gods, hoping that the weather was good, the harvest was good, and the disaster was destroyed. For local officials and social elites, a combination of tough rules and regulations and local religions can more moderately achieve the goal of environmental protection.

\section{A. The Government}

Local governments, as organizers, managers and supervisors of social activities, have realized that the impact of planting high-yielding crops on the local environment has been devastating. However, as far as the entire social situation in the late Qing and Southern Shaanxi was concerned, the removal of immigrants and the prohibition of reclamation were not an option. Therefore, in order to restore vegetation, the government could take the following measures: Firstly, to use the people's worship for the gods and fear of being punished by heaven, in the name of Fengshui, to erect mountains in order to restore vegetation and mitigate disasters purpose. This had been recorded in the steles that were preserved in Hanzhong and Ankang. Fengshui is a unique cultural phenomenon in ancient China. It believes that the trees related to "Long Mai" cannot be felled, and the land cannot be reclaimed. For example, in Baihe, Shaanxi Province, in 1868, the stone was established, and after the county was located in the mountainous area, "This was where the dragon must go, so no one was allowed to damaged." Otherwise, "the crime of invading and destroying the city is ruled"; Pingli in 1880, "Shi Ziba and Xing Pingbao's fengshui was good and important... ... no matter what the industry belongs to everyone, around the upper and lower must not be destroyed."[1] Second, the local government imposed a ban on compulsory enforcement and it was strictly prohibited. In the early years of Daoguang Emperor, Fang Chuanen, a county official in Xixiang, Shaanxi Province, also asked the official to build a stele. "Ever since the closure of the North Mountain" would be issued to the public to "never breed" and "get off the knot". [9] Third, Encourage planting more trees.During Chen Hongmou's governorship in Shaanxi Province, He visited many places in Shaanxi and thought that "narrow fields and difficulties in food and clothing. The transportation was inconvenient and the wood was difficult to transport outside." However, "The medicinal herbs, bamboo, edible fungus, camphor, walnuts, chestnuts, and palm trees were among them. It could be used for food, but it could also be used for selling money, now the mountains and waters can be planted in the most places. Ten years later, you can build houses and you can also sell money." [10] Although the original intention of the government to encourage trees was to maintain the livelihood of the farmers, Soil erosion was more likely to occur in areas with steep slopes, and extensive advice on planting trees also played a role in preventing soil erosion. 
Fourth, Zhao Guo's "Dai Tianfa" was promoted to conserve soil strength or fallow for one year or two years, and teached people to use manure as fertilizer. [11] In order to reduce soil erosion.

For the banned areas, local governments have also formulated corresponding measures to ensure the implementation of the policies and to punish those who stole and dig. For example, in Ying Tai Xiang, Pingli country, there had a stele during the Daoguang Emperor period said, "The land is not allowed to be cut down, stolen, set fire to the mountains. If it is not followed, the violators will be penalized for one show and three seats for wine and price compensation." [11] For those who set fire to the mountain, they should not only be given financial penalties, but also use local forms of opera to promote the prohibition of deforestation. For areas that the government had already ordered to ban, the planting trees were encouraged to be severely punished if they contravene the excavation and planting. Local magistrates "limit the localities to send two people to take turns to go uphill every season......Many trees are still planted, including tung, chun and chestnut trees. and if anyone violates the ban and farmland grows grain, he will be severely punished." [12]

\section{B. Local Social Elite}

Ancient China was a patriarchal society, where local social elites tend to be family leaders, or villages gentry, and they maybe also well-known rich locals. They had a high degree of public trust in the hearts of the people. Folk contradictions and disputes, funeral ceremonies were often led by them. Therefore, in terms of environmental protection, they may be able to play a greater role than the government. And when local governments were unable to monitor because of insufficient numbers, they were more willing to maintain local elites or maintain elite decisions.

The environmental protection measures of local elites mainly included the following: Firstly, coordinate the contradiction between farmers and landowners and ensure the maximization of interests. In the irrigation area of Jin Yangyan, "every time the seedlings show up, breezes, the leaves gradually turn red, and wheat ears gradually turn white, through God's way, it cannot be saved." In the early years of Tongzhi, they were affected by the war. The surrounding kiln factory was shut down, and the food production was very good, so the local people "convening the flow of the East Coast gentry, after consultation, it was decided that no kiln should be allowed to open in the vicinity of the canal. If someone continued to burn the kiln and impede the normal growth of the food crop, the chief of the management dike would lead the workers and destroy his Kiln factory. If the lawsuit arises because of this, the money would be allocated to the field to determine the outcome." [13] In the end, the kiln factory reached an agreement with the local people to open a factory for kiln firing without affecting agricultural production. This not only safeguarded agricultural production, but also ensured the economic development of the local kiln, and also reduces the demand for the environment, killed two birds with one stone. Second, local elites paid for land, stopped planting trees, and restored vegetation. In the late Qing dynasty, for areas not suitable for cultivation, or areas where water and soil were lost due to the loss of sand and sand after land reclamation, some well-informed people from southern Shaanxi actively invested in planting and planting grass to restore vegetation. "After investigating the area along the slope of the Huang Caoping, approached the canal, although it was different from a place full of stones, it was not a fertile soil. The landowners in this area had only a small amount of food at a time due to their small benefits. The slope was steep the sand veins were loosened, summer and rain fall, the water and sand are mixed, and it was harmful to the channels. Now every year Qi school subsidized the landlord, the three buckets of rice, and it was not allowed to dig after planting. The tree is still planted by the school. Wood, when read in the future, has a long history, roots deep in the soil, and has a long and tight soil, which is of great benefit to the channel. Still, there are plenty of tuition fees, and the price will be paid for and the dispute will be broken." [14] Some merchants, after realizing that they have been harmed by over-harvesting, are actively investing to purchase barren hills, fields and plant trees. "Restoration of HuXian County" records, "He Yulin and his uncle came to live in the mouth, and then he started with a wood merchant. He has huge capital, and the village south Ma Weipo. Every time the storm waters, the villagers always complain about the rain. Yu Lin generously donated money to buy thousands of acres of land from the mountains to the forest and flooding gradually disappeared." [15]

The environmental problems such as soil erosion in southern Shaanxi are not formed overnight. The solution to the famine problem depends on high-yield crops, and the contradiction between excessive population growth and environmental pressure cannot be reconciled within a short time. Therefore, whether it is an official or local elite the environmental measures taken by the groups can only be alleviated slightly and cannot completely solve the problem of environmental pressure.

\section{CONCLUSION}

The main conclusions of this paper as follows:

- Population increase promotes the expansion of corn planting in mountain areas, and corn was also an important guarantee for promoting economic development and social stability in mountain areas.

- Sweet potatoes are the emergency relief crops, while potatoes were the "save food" of the alpine cold regions. They were all measures that the small-scale peasant economy had developed to the "technical top limit" and were forced to adopt to deal with the food crisis.

- While promoting the development of mountainous areas in southern Shaanxi, American crops had caused damages to the ecological environment because of population growth, climate change, and changes in domestic economic development patterns.

- Environmental protection measures established by local officials and social elites couldnot reverse the deterioration of the natural environment in southern Shaanxi. 
The issue of population and land was the basis for the local officials in southern Shaanxi to solve the problem of famine. However, the fact that there were too many people in southern Shaanxi was an irreconcilable contradiction. In order to survive and maintain social stability, local officials had to sacrifice the cost of the environment. The cultivation of American crops in southern Shaanxi in the Qing Dynasty and the resulting environmental changes had so far affected the social development in southern Shaanxi.

\section{REFERENCES}

[1] Zhang Xiangwen. Soil and Water Loss Caused by corn Planting in the Mountains in the Middle and Late Qing Dynasty and Measures for Containment. Chinese Agricultural History, 2006, (3): 13-21. (In Chinese)

[2] Wang Xinghong.Agricultural Development and Ecological Changes in the Qinling Mountains and Daba Mountains in the Qing Dynasty.Journal of Hainan Normal University (social sciences ), 2003,16(5):111-114.

[3] Zhao Yongxiang.Nanshan Virgin Forest:the Forest Region's Governance and Ecological Environment of the South Qinlin Mountain in the Qing Dynasty.Chinese Agricultural History,2005,(3):101-112

[4] Yan RuyI: "Introduction to the Homeland of the Three Provinces"(In Chinese)

[5] Yan Ruyi: "The preparation of border defense in three provinces" volume eight "people's food."(In Chinese)

[6] Mark Elvin.The Retreat of the Elephants:An Environmental History of China.America:Yale University Press, 2004.

[7] Lu Kun: "QinJiang governance."(In Chinese)

[8] Wang Lihua. Viewing "Knowledge" and "Make" of Ecological Civilization Construction from the Perspective of Environmental History. People's Daily. Theory, 27,10,2013. (In Chinese)

[9] Zhao Gang.Policy for Cultivation and Shelter Activities in the Qing Dynasty.Theory of Chinese Historical Area,1995, (3):27-46.(In Chinese)

[10] He Changling: "Emperor of the Kingdom of the World" vol.28,"Bing Dynasty thirteen. Mountain defense."(In Chinese)

[11] He Changling series: "Emperor of the Emperor of the World Series," vol.28. (In Chinese)

[12] Republic of China: "Continuation of Shaanxi Tongzhi Manuscript" Volume 60, "Water Conservancy IV, Hanzhongfu, Xixiang County". (In Chinese)

[13] Chen Xianyuan. Monument Stone in Hanzhong. Xi'an: Sanqin Press, 1996. (In Chinese)

[14] ShaanxiProvincial Ancient Books Office Zhang Pei. Anking Steles. Xi'an: Sanqin Press, 1991. (In Chinese)

[15] Republic of China: "Continuation of Shaanxi Tongzhi Manuscript" Vol. 60, "Water Conservancy 4, Hanzhongfu, Xixiang County". Printed in, pp. 33-34 1934. (In Chinese). 